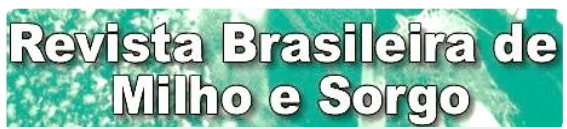

Brazilian Journal of Maize and Sorghum

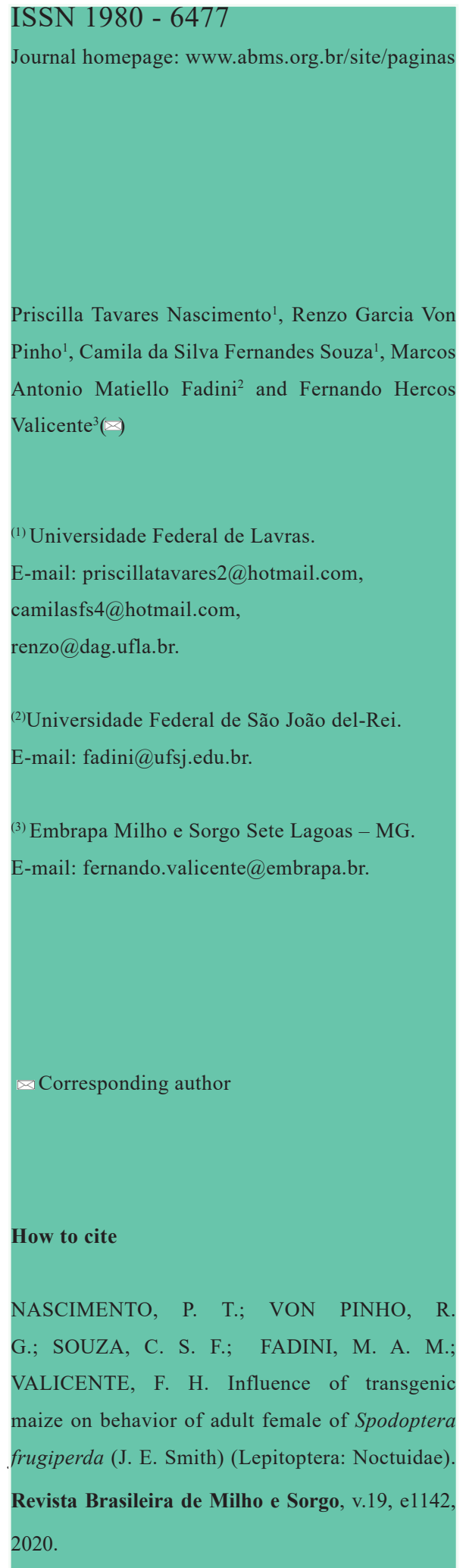

\section{INFLUENCE OF TRANSGENIC MAIZE ON BEHAVIOR OF ADULT FEMALE OF Spodoptera frugiperda (J. E. SMITH) (LEPIDOPTERA: NOCTUIDAE)}

\begin{abstract}
Genetic manipulation of plants can cause pleiotropic effects or mutations originated from the incorporation of an exogenous gene, which may interfere with foraging behavior of herbivores. Little is known about how herbicide-tolerant plants (singular event), insect-resistant plants (singular event), and herbicide-tolerant plus insect-resistant plants (stacked event) affect foraging of Spodoptera frugiperda. The objective of this study was to evaluate if singular and stacked maize events interfere with the quantity and quality of $S$. frugiperda egg. The hybrids DKB390 (VTPRO, VTPRO2, VTPRO3), DKB390 (isogenic) and Ag 3700 RR2 were evaluated. Choice and non-choice tests for oviposition preference of $S$. frugiperda, in plants with and without injuries, were performed in a greenhouse. The size of egg masses and the number of hatched eggs were evaluated. Larger egg masses and higher number of hatched eggs per plant were found in transgenic plants. The conclusion was that $S$. frugiperda females modify their oviposition behavior in the presence of transgenic and non-transgenic maize hybrids, especially when they are injured. However, the females did not discriminate between singular or stacked hybrid for oviposition.
\end{abstract}

Keywords: Zea mays, transgenesis, fall armyworm, plant-herbivore interaction.

\section{INFLUÊNCIA DO MILHO TRANSGÊNICO NO COMPORTAMENTO DE FÊMEAS ADULTAS DE Spodoptera frugiperda (J. E. SMITH) (LEPIDOPTERA: NOCTUIDAE)}

Resumo - A manipulação genética de plantas pode causar efeitos pleiotróficos ou mutações oriundas da incorporação de um gene exógeno, os quais podem interferir no forrageamento de herbívoros. Pouco se conhece sobre os efeitos de plantas de milho tolerantes a herbicidas (evento singular), plantas resistentes a insetos (evento singular) e plantas com tolerância a herbicidas e resistência a insetos (evento estaqueado) sobre o forrageamento de Spodoptera frugiperda. O objetivo deste estudo foi avaliar se eventos de milho, singular e estaqueado, interferem na quantidade e qualidade dos ovos de $S$. frugiperda. Foram avaliados os híbridos DKB390 (VTPRO, VTPRO2, VTPRO3), DKB390 (isogênico) e Ag 3700 RR2. Testes de preferência de oviposição, com e sem chance de escolha, em plantas com e sem injúrias, por $S$. frugiperda foram realizados em casa de vegetação. Avaliouse o tamanho da massa de ovos e o número de lagartas eclodidas. Em plantas transgênicas, foram observadas massas de ovos de maior tamanho e maior número de lagartas eclodidas por planta. Conclui-se que fêmeas de S. frugiperda modificam o comportamento de oviposição diante de híbridos de milho transgênico e não transgênico, principalmente quando os híbridos apresentam injúrias. No entanto, não discriminaram entre híbrido singular ou estaqueado para oviposição.

Palavras-chave: Zea mays, transgenia, lagarta-militar, interação planta-herbívoro. 
There is a direct interaction between insects and their host plants. For lepidopteran insects, for example, feeding is not the first contact between plants and herbivores (Refsnider \& Janzen, 2010) but rather oviposition (Hilker \& Meiners, 2006). Females use chemical receptors that detect odors released by the plant, which are used for feeding and oviposition, besides being useful to detect the presence of conspecifics (Hilker \& Meiners, 2006).

Fall armyworm, Spodoptera frugiperda (J. E. Smith) (Lepidoptera: Noctuidae) is a cosmopolitan and phytophagous insect species, native to tropical and subtropical regions of the Americas, where it is widely distributed (Cruz, 1995), and more recently, also in Africa and Asia (Montezano et al., 2018). Despite being a polyphagous insect, with more than 353 host plant species registered (Montezano et al., 2018), $S$. frugiperda is considered the major insect pest in maize, being capable of causing damage practically in all developmental stages (Dequech et al., 2013). After mating, females oviposit, preferably on the abaxial surface of leaves (Pitre et al., 1983). The number of egg depositions varies, and, in some cases, a female can perform up to 13 egg depositions (Cruz, 1995). Masses are irregular and may contain from 30 to 300 eggs.

Molecular biology, an important tool in agricultural pest control, has enabled the genetic manipulation of plants (Schuler et al., 1999). The use of transgenic crops, such as those that produce insecticidal proteins from the bacterium
Bacillus thuringiensis (Bt), for example, enabled the use of a new and efficient strategy for Integrated Pest Management (IPM) (Storer et al., 2012). Bt represents a rich source of genes to be used in the production of genetically modified organisms. Out of the 76 events of genetically modified (GM) plants approved in Brazil, 43 express Bt genes plus herbicide genes or only Bt genes, cloned in soybean, cotton, sugar cane and maize crops (CTNBio 2018).

To broaden the target range, delay the evolution of pest resistance and simplify crop management, multiple Cry proteins were combined in genetically modified plants (Head et al., 2017). Furthermore, plants with multiple characteristics, such as herbicide tolerance and insect resistance, become increasingly important (ISAAA, 2018). Currently, there is availability of hybrids with stacked events, which present one or more Cry proteins in addition to herbicide tolerance, and plants with singular events, which can present insecticidal protein or herbicide tolerance (ISAAA, 2018).

Some studies assessed the oviposition preference of moths for $\mathrm{Bt}$ and non-Bt hybrids (Kjaer et al., 2010; Hardke et al., 2012; TéllezRodríguez et al., 2014; Rojas et al., 2018). However, evaluations were not carried out to compare singular and stacked events. Moreover, such studies assessed non-injured crops, i.e, ignoring any influence of plant defoliation on the choice behavior of herbivores. In addition, the genetic manipulation of a certain trait that improves the varieties of agricultural plant 
species, such as Bt plants or herbicide-resistant plants, can affect other traits, as a result of possible pleiotropic effects of insertion, mutations that can directly affect the interaction between the plant and other organisms (Schuler et al., 1999).

Therefore, due to the intensive use of $\mathrm{Bt}$ technologies and especially to the adoption of pyramided events, the objective of this study was to evaluate if singular and stacked maize events interfere with the quantity and quality of S. frugiperda egg masses.

\section{Material and Methods}

\section{Plant cultivation}

The experiment was conducted at Embrapa Maize and Sorghum, in Sete Lagoas, MG. Plants were maintained in the greenhouse $\left(25 \pm 5{ }^{\circ} \mathrm{C}\right.$, $70 \pm 15 \%$ UR, 14-hour photophase). Maize hybrids used were DKB390 YieldGard, VT PRO тм (cry1A.105 and cry2Ab2), DKB390, VT PRO $2^{\text {TM }}$ (cry1A.105, cry2Ab2 and glyphosatetolerant), DKB390 VT PRO $3^{\circledR}$ (cry1A.105, cry2Ab2, cry3Bb1 and glyphosate-tolerant), $\mathrm{Ag}$ 3700 RR2 (CP4 EPSPS, glyphosate-tolerant) and DKB390 (non-Bt maize), obtained from Dekalb (Monsanto, St. Louis, USA). They were planted in polyethylene pots $(2 \mathrm{~L})$ with $1.5 \mathrm{~kg}$ of soil. Maize plants used in the bioassays had been growing for 10-12 days after emergence and had three fully expanded leaves (V3), in which plants are naturally attacked by $S$. frugiperda (Cruz \& Turpin 1982). Plants were kept in greenhouse $\left(25 \pm 5^{\circ} \mathrm{C} ; 70 \pm 15 \% \mathrm{UR} ; 14 \mathrm{~h}\right)$, and irrigated every other day.

\section{Insects used in the experiments}

S. frugiperda adults were placed in polyvinyl chloride (PVC) tube cages $(20-\mathrm{cm}$ diameter and 30-cm height). Paper napkins were used as oviposition substrate, were placed inside each cage. A sucrose solution ( $25 \mathrm{~g}$ of sugar, $1 \mathrm{~g}$ of ascorbic acid, $1 \mathrm{~g}$ of maize glucose in $1000 \mathrm{~mL}$ of distilled water) was offered to the adults. After four days, paper napkins with the eggs were removed, placed into plastic bags, and stored in a room under controlled conditions $\left(25 \pm 1{ }^{\circ} \mathrm{C}\right.$; UR $70 \pm 10 \%$ and 12 -hour photophase). The newly hatched eggs were individually transferred to 50 $\mathrm{mL}$ plastic cups with artificial diet (Valicente \& Barreto, 2003), where larvae developed up to 7 days, individualized until reaching the adult stage. The adults were transferred to the cages, starting a new life cycle.

\section{Tests to evaluate oviposition (Non-choice test)}

Cages $(0.7 \mathrm{~m}$ wide $\times 0.7 \mathrm{~m}$ long $\times 1.0$ $\mathrm{m}$ high) were made of wood and covered with voile. In the center of the cage, only one vase of each hybrid tested was placed. After this step, two mated females, 3-4 days old, were released for oviposition. After two scotophases, the plants were removed from the cage for evaluation, being the egg masses classified as small, medium, 
and large. The number of eggs in the layered egg masses was estimated by multiplying the number of eggs in the upper layer by the number of layers and then adding up the eggs on the margins of subsequent layers (Leuck \& Perkins, 1972). The eggs were stored in $50 \mathrm{~mL}$ plastic cups, where they were kept under controlled conditions $\left(25 \pm 1{ }^{\circ} \mathrm{C}\right.$; UR $70 \pm 10 \%$ and 12 hour photophase), until the larvae hatching from eggs, with registration of the number of newly hatched larvae (NHL) in each hybrid. Tests were conducted in a completely randomized design, where each cage with one plant pot corresponded to one replication $($ No. $=12)$.

\section{Tests to evaluate oviposition (choice test)}

Bt hybrids VT PRO, VT PRO 2, VTPRO3, RR2, and their isolines were distributed equally within the cages $(0.7 \mathrm{~m}$ wide $\times 0.7 \mathrm{~m}$ long $\times 1.0$ $\mathrm{m}$ high), five treatments with multi-choice were assayed per cage with one plant of each hybrid. Subsequently, 10 mated females of S. frugiperda, 3-4 days old, were released in each cage. After two scotophases, plants were removed from the cage for evaluation, and the egg masses classified as small (less than 20 eggs/mass), medium (between 20 and 100 eggs/mass) and large (more than 100 eggs/mass). Eggs were stored in $50 \mathrm{~mL}$ plastic cups, under controlled conditions, $(25 \pm 1$ ${ }^{\circ} \mathrm{C}$; UR $70 \pm 10 \%$ and 12 -hour photophase), until the larvae hatching from eggs, with registration of NHL in each hybrid. Tests were conducted in a completely randomized design, where each cage with plant pots corresponded to one replication $($ No. $=12)$.

\section{Oviposition evaluation in injured plants}

Mated females of $S$. frugiperda were exposed to injured maize plants for oviposition. The injured plants were obtained through the confinement of third-instar larvae in small cages (clip cage) of $3.5 \mathrm{~cm}$ diameter. Five larvae were kept in each cage. Infestations occurred from 08:00 a.m. to 02:00 p.m., with the larvae were in contact with the plants for six hours. After the infestation period, larvae were removed from the plants and tests were conducted.

Subsequently, plants were placed inside the cages $(0.7 \mathrm{~m}$ wide $\times 0.7 \mathrm{~m}$ long $\times 1.0 \mathrm{~m}$ high), the same cages used for the tests in non-injured plants. At 04:00 p.m., females were released in the cages for $48 \mathrm{~h}$. At the end of this period, plants were removed from the cages and the egg masses were evaluated and classified as small, medium and large. Eggs were stored in $50 \mathrm{~mL}$ plastic cups. After egg hatching, NHL in each hybrid was registered. Test was replicated 12 times and was conducted under controlled conditions (25 $\pm 1{ }^{\circ} \mathrm{C}$; UR $70 \pm 10 \%$ and 12-hour photophase). Both choice and non-choice tests were carried out in injured plants. In the non-choice test, only one injured hybrid was exposed for oviposition, while in the choice test, all injured hybrids analysed were exposed to the moths for oviposition. To control the plant volatile emissions in response to larvae herbivory, each hybrid treatment was 
tested individually in the non-choice tests.

Data relative to oviposition, size of egg masses and number of newly hatched larvae were submitted to generalized linear model (GLM), analysis of variance (ANOVA F-test), and mean separation using Scott-Knott's test, at 0.05\% level of significance (Crawley 2013). Analyses were performed with the use of $\mathrm{R}$ software ( $\mathrm{R}$ Development Core Team, 2014).

\section{Results and Discussion}

\section{Oviposition evaluation (non-choice tests in non-injured plants)}

In tests where the moth was exposed to only one non-injured material, $\mathrm{Bt}$ and non-Bt hybrids influenced the egg masses deposition (Fig. 1A; $\mathrm{F}=3.85, \mathrm{GL}=4, \mathrm{P}<0.001$ ). Results demonstrate that the hybrids RR2, PRO and PRO3 presented a higher number of small egg masses (Fig.1A; $\mathrm{F}=2.185, \mathrm{GL}=4, \mathrm{P}<0.001$ ). However, isogenic hybrid DKB390 presented a higher number of medium-sized egg masses (Fig.1A; F=4.285, GL=4, $\mathrm{P}<0.001$ ). Moreover, the hybrids RR2 and PRO3 presented a higher number of size egg masses (Fig. 1A; F=2.60, $\mathrm{GL}=4, \mathrm{P}<0.01$ ), whereas the moths deposited fewer large egg masses in the hybrids DKB390 and PRO2 (Fig.1A; F= 2.314, $\mathrm{GL}=4, \mathrm{P}<0.01$ ).

The number of hatched eggs (NHE) was observed in the hybrids PRO3 and RR2 (Fig. 3; $\mathrm{F}=2.662, \mathrm{GL}=4, \mathrm{P}<0.01)$.

\section{Oviposition evaluation (choice tests in non- injured plants)}

In tests where all hybrids were available for egg deposition, differences between transgenic and non-transgenic hybrids were observed (Fig.1B; F=2.068, GL=4, $\mathrm{P}<0.001$ ). Hybrids RR2 (Fig.1B; F=2.216, $G L=4, P<0.05$ ) and PRO3 (Fig.1B; F=2.683, GL=4, P<0.01) presented the highest number of small egg size depositions. The RR2 (Fig.1B; $F=3.040, G L=4$, $\mathrm{P}<0.05$ ), PRO (Fig.1B; $\mathrm{F}=3.139, \quad \mathrm{GL}=4, \mathrm{P}<$ 0.001), PRO2 (Fig. 1B; F=2.821, GL=4, $\mathrm{P}<0.01$ ) and PRO3 (Fig.1B; F=2.049, $\mathrm{GL}=4, \mathrm{P}<0.05$ ) were the hybrids with the highest number of medium-sized egg masses. Hybrids PRO (Fig.1B; $\mathrm{F}=2.030, \mathrm{GL}=4, \mathrm{P}<0.05$ ) and $\mathrm{PRO} 2$ (Fig.1B; $\mathrm{F}=2.170, \mathrm{GL}=4, \mathrm{P}<0.05$ ), a higher number of large egg size masses was found. DKB390 was the hybrid with lower number of egg masses (small and medium), it also presented lower values of NHL (Fig.3B; F=3.373, $\mathrm{GL}=4, \mathrm{P}<0.001$ ). The transgenic hybrids RR2 (Fig.3B; F=3.068, $\mathrm{GL}=4, \mathrm{P}<0.01$ ), PRO (Fig.3B; $\mathrm{F}=4.064, \mathrm{GL}=4$, $\mathrm{P}<0.001$ ), VTPRO2 (Fig.3B; $\mathrm{F}=3.626, \mathrm{GL}=4$, $\mathrm{P}<0.001$ ), and VTPRO3 (Fig.3B; $\mathrm{F}=2.529$, $\mathrm{GL}=4, \mathrm{P}<0.05)$ presented the highest values of NHL.

\section{Oviposition evaluation (non-choice tests in injured plants)}

In the cages, when only one injured hybrid was available for the adult female of $S$. frugiperda, 
A)
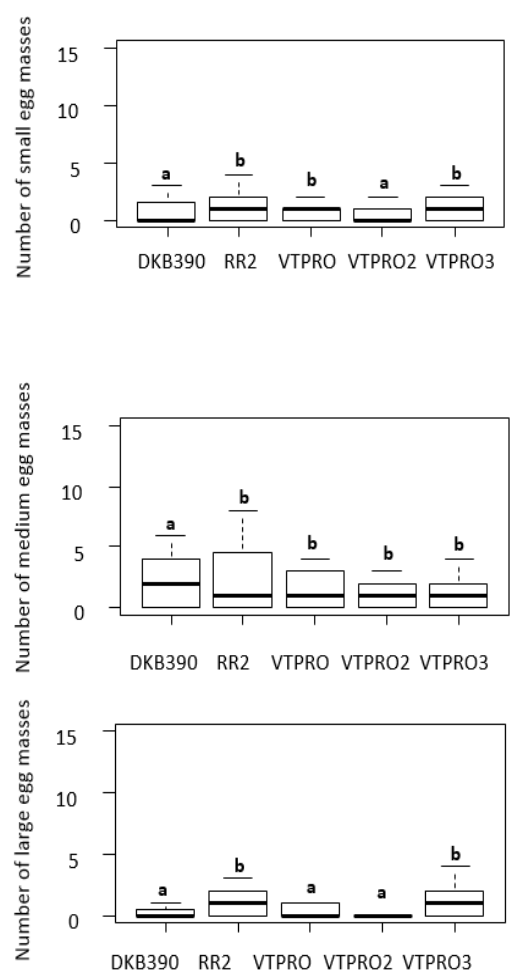

B)
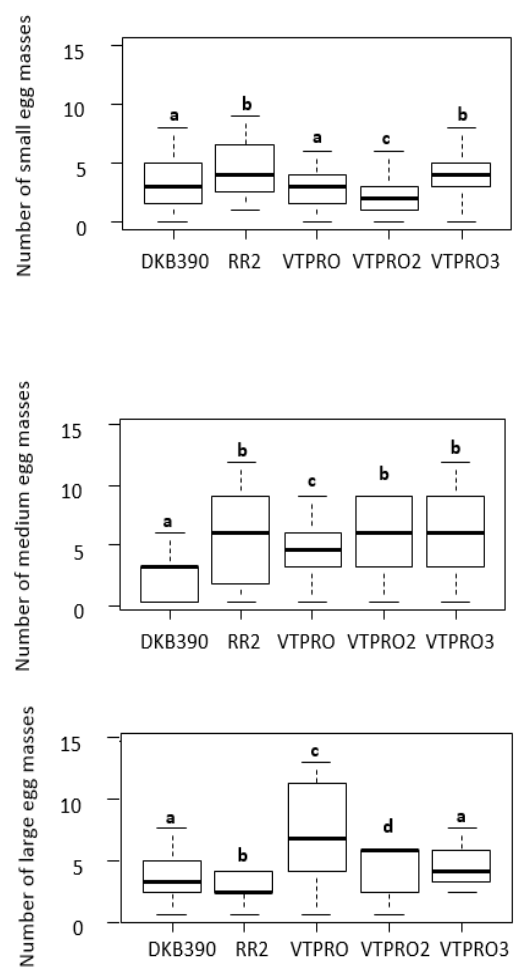

Figure 1. Number of small, medium and large size egg masses, deposited by females of Spodoptera frugiperda, in different Bt and non-Bt maize hybrids. Experiments conducted with no choice (A) and with choice (B) in non-injured plants.

both hybrid and the infestation interfered with egg masses sizes (Fig.2; $\mathrm{F}=4.628, \mathrm{GL}=4, \mathrm{P}<0.001$ ). The hybrids RR2 and PRO3 presented higher values of small egg size masses (Fig.2; $F=1.428$, $\mathrm{GL}=4, \mathrm{P}<0.01)$. The Bt hybrid RR2 presented the highest number of newly hatched larvae (Fig.3C; $\mathrm{F}=2.093, \mathrm{GL}=4, \mathrm{P}<0.05)$.

Oviposition evaluation (choice tests in injured plants)

In tests where all injured hybrids were available for oviposition, there were significant differences between transgenic and nontransgenic hybrids (Fig.2B; $\mathrm{F}=3.821, \mathrm{GL}=4$, $\mathrm{P}<0.01$ ), in addition to a negative effect of infestation (Fig.2B, $\mathrm{F}=-3.457, \mathrm{GL}=4, \mathrm{P}<0.001$ ). The transgenic hybrids RR2 (Fig.2B; F=2.216, $\mathrm{GL}=4, \mathrm{P}<0.05$ ), PRO (Fig.2B; $\mathrm{F}=2.134, \mathrm{GL}=4$, $\mathrm{P}<0.05$ ), $\quad \mathrm{PRO} 2 \quad$ (Fig.2B; $\mathrm{F}=3.087, \quad \mathrm{GL}=4$, $\mathrm{P}<0.05$ ) and VTPRO3 (Fig.2B; $\mathrm{F}=2.683, \mathrm{GL}=4$, $\mathrm{P}<0.001)$ presented a higher number of small egg masses. The hybrids RR2 (Fig.2B; F= 3.139, $\mathrm{GL}=4, \mathrm{P}<0.001$ ) and VTPRO3 (Fig.2B; F=2.049, 
$\mathrm{GL}=4, \mathrm{P}<0.05$ ) presented a higher number of medium-sized egg depositions. In the transgenic hybrids RR2 (Fig.2B; $\mathrm{F}=2.119, \mathrm{GL}=4, \mathrm{P}<0.05$ ), $\mathrm{PRO} 2$ (Fig.2B; $\mathrm{F}=3.515, \mathrm{GL}=4, \mathrm{P}<0.05$ ) and $\mathrm{PRO} 3$ (Fig.2B; $\mathrm{F}=3.124, \mathrm{GL}=4, \mathrm{P}<0.05$ ), higher values of large size egg masses were found.

Since there was an effect in egg deposition, the number of NHE was negatively influenced by the infestation (Fig.3D; F=3.226; $\mathrm{P}<0.001)$. However, even with negative effect, the transgenic hybrids presented higher number of NHE when compared with the isogenic, due to the fact that they were the most preferred in

A)
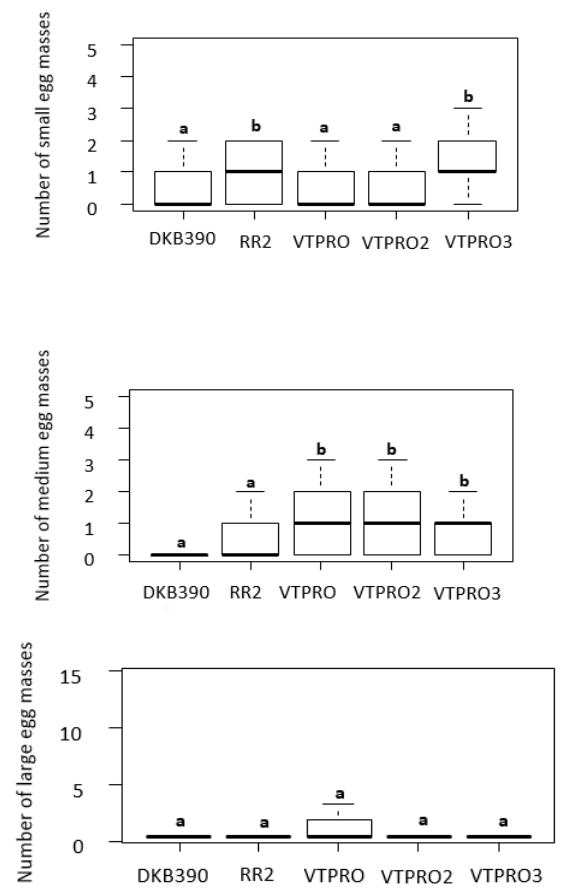

the choice tests: RR2 (Fig.3D; F=3.027, GL=4, $\mathrm{P}<0.01$ ), VTPRO (Fig.3D; $\mathrm{F}=4.009, \quad \mathrm{GL}=4$, $\mathrm{P}<0.001$ ), VTPRO2 (Fig.3D; $\mathrm{F}=3.577, \mathrm{GL}=4$, $\mathrm{P}<0.001$ ), and VTPRO3 (Fig.3D; $\mathrm{F}=2.495$, $\mathrm{GL}=4, \mathrm{P}<0.05$ ).

The results show that adult females of $S$. frugiperda select the host plant for oviposition differently depending on if the maize hybrid is transgenic or not. In general, females lay larger egg masses size, and in higher number in transgenic hybrids, that directly influences the number of newly hatched eggs on the plants. Additionally, although females show oviposition preference for transgenic maize hybrids, there

B)
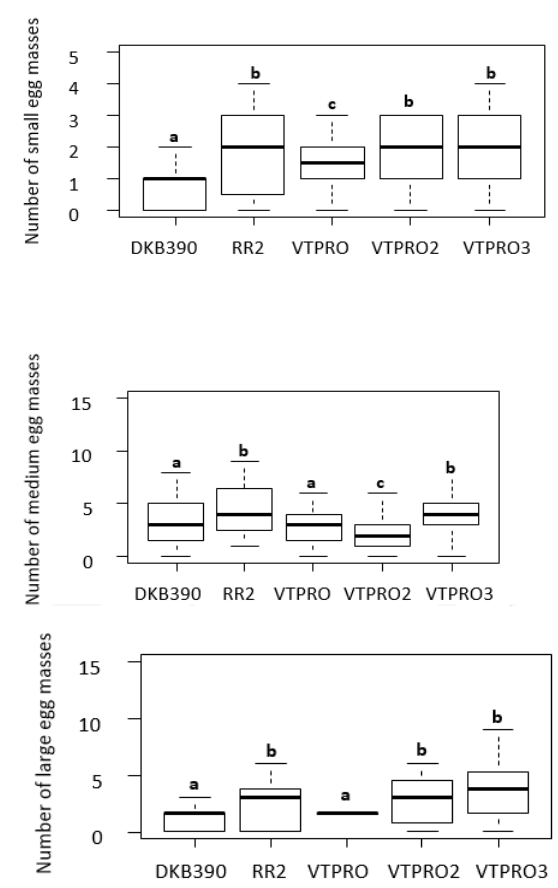

Figure 2. Number of small, medium and large size egg masses, deposited by females of Spodoptera frugiperda, in different Bt and non-Bt maize hybrids. Experiments conducted with no choice (A) and with choice (B) in injured plants. 
A)

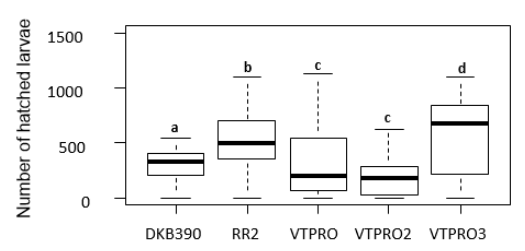

B)

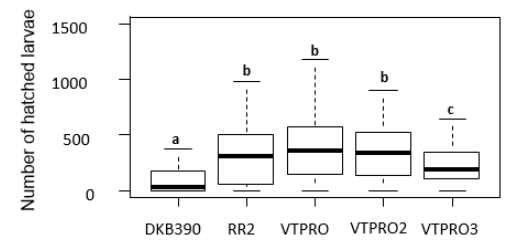

C)

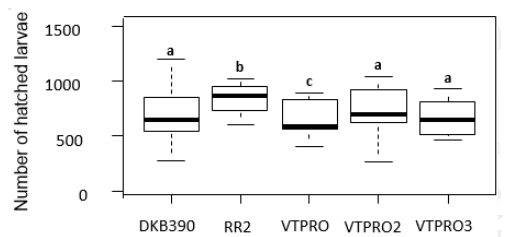

D)

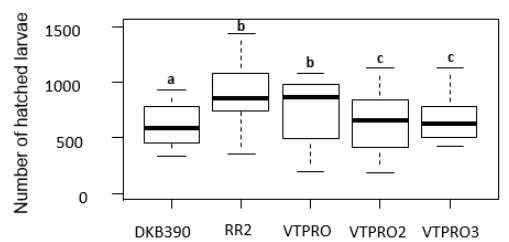

Figure 3. Number of hatched larvae (NHL) of Spodoptera frugiperda, in different Bt and non-Bt maize hybrids. Experiment conducted with no choice in non-injured plants (A), with choice in non-injured plants (B), with no choice in injured plants (C) with choice in injured plants (D).

was no preference regarding the choice between singular and stacked materials.

Host plant selection involves a number of factors, thus the females are likely to select hosts based on the offspring performance, risk of mortality due to natural enemies and nutritional quality (Thompson, 1988; Refsnider \& Janzen, 2010). In non-injured plants, S. frugiperda laid eggs equally in both transgenic and nontransgenic hybrids. However, differences in oviposition were noticed in injured plants. Results found in the present study demonstrates that moths selected the injured transgenic plants, particularly Bt plants, with the purpose to decrease offspring competition. Moreover, it is known that the oviposition-site choice of $S$. frugiperda is affected by maize plant volatiles (Peñaflor et al., 2011). Females preferred to oviposit on plants with lower levels of injury, on Bt hybrids, which release volatiles that are different from the isogenic version (Téllez-Rodríguez et al., 2014).
It is possible that the moths can perceive and identify these differences, and select the specific host. Moths of $S$. frugiperda would avoid host plants that were already selected, by their conspecifics, based on this mixture of chemical compounds induced by previous herbivory.

This perception involves a process coevolutionary between the maize plant and $S$. frugiperda (Musser et al., 2002). Therefore, adult females may identify higher levels of injury, which modifies the chemical profile in relation to the isogenic version. These herbivore-induced volatile compounds interfere directly with the insect-plant communication and the signalling for natural enemies (Fatouros et al., 2012). Consequently, moths do not select plants with high levels of injury, where there is a higher chance of attack by predators and parasitoids (Lei et al., 2009). Sparks (1979) also observed that the oviposition behavior of $S$. frugiperda changes when there are different larval densities 
on the plant, thus confirming the hypothesis proposed in this study that the egg mass laid by moths would be associated with injury rates. Thompson (1988) reported that the host selection is not only affected by food quality, and proposed the enemy free space hypothesis, which assumes that herbivores may prefer nutritionally inferior host plants, but that are free of natural enemies.

Some studies investigated oviposition preference and found that females do not discriminate between transgenic cultivars and the isogenic (Lei et al., 2009). However, these studies investigated only the number of eggs in non-injured plants, ignoring any potential effect of subsequent larval feeding on the adult female behavior. Since many Bt crops kill newly emerged larvae, the feeding injury caused by larvae differs between $\mathrm{Bt}$ and non-Bt crops. However, even Bt plants can release volatiles during larval feeding that may repulse oviposition of females, thus reducing, intraspecific competition or modifying the behavior of enemies that use such volatiles as foraging cues (De Moraes et al., 2001).

These results are relevant for resistance management. Among insects that select Bt plants for oviposition, there is probability that resistant individuals to $\mathrm{Bt}$ maize will emerge, due to selection pressure. Resistance management strategies should consider the behavior of adults because at this developmental stage, these lepidopterans may choose a host plant.

\section{Conclusions}

Adult females of $S$. frugiperda change their oviposition behavior in the presence of transgenic (VTPRO, VTPRO2, VTPRO3 and RR2), and non-transgenic (DKB390) maize hybrids, especially when the plants have injuries. The highest number of egg masses was laid in transgenic hybrids. Females of $S$. frugiperda did not discriminate between singular or stacked hybrid for oviposition.

\section{Acknowledgments}

The authors thank the Coordination for the Improvement of Higher Education Personnel (CAPES) and the Brazilian National Council for Scientific and Technological Development (CNPq) for the financial support for project development.

\section{References}

COMISSÃO TÉCNICA NACIONAL DE BIOSSEGURANÇA. Tabela de plantas: uso comercial. Disponível em: <http://ctnbio. mctic.gov.br/liberacao-comercial/-/document library_display/SqhWdohU4BvU/view/16844 67; jsessionid=2EDD3 DC 75D56C 190497322 F4C6DD3210.columba\#/liberacao-comercial/ consultar-processo>. Acesso em: 13 jul. 2019.

CRAWLEY, M. J. The $\mathbf{R}$ book. 2nd ed. Chichester: JohnWiley \& Sons, 2013.

CRUZ, I. A lagarta-do-cartucho na cultura do 
milho. Sete Lagoas: Embrapa-CNPMS, 1995. 45 p. (Embrapa-CNPMS. Circular Técnica, 21).

DE MORAES, C. M.; MESCHER, M. C.; TUMLINSON, J. H. Caterpillar-induced noctural plant volatiles repel conspecific females. Nature, v. 410, p. 577-580, 2001.

DEQUECH, S. T. B.; CAMERA, C.; STURZA, V. S.; RIBEIRO, L. do P.; QUERINO, R. B.; PONCIO, S. Population fluctuation of Spodoptera frugiperda eggs and natural parasitism by Trichogramma in maize. Acta Scientiarum Agronomy, v. 35, n. 3, p. 295-300, 2013. DOI: 10.4025/actasciagron.v35i3.16769.

FATOUROS, N. E.; LUCAS-BARBOSA, D.; WELDEGERGIS, B. T.; PASHALIDOU, F. G.; VAN LOON, J. J.; DICKE, M.; HARVEY, J. A.; GOLS, R.; HUIGENS, M. E. Plant volatiles induced by herbivore egg deposition affect insects of different trophic levels. PLOS ONE, v. 7, n. 8 , e43607, 2012. DOI: 10.1371/journal. pone. 0043607 .

HARDKE, J. T.; LEONARD, B. R.; TEMPLE, J. H. Fall armyworm oviposition on cotton plants expressing wide strike (TM) Bollgard (R), and Bollgard II (R) Cry proteins. The Southwestern Entomologist, v. 37, n. 3, p. 295-303, 2012.

HEAD, G. P.; CARROLL, M. W.; EVANS, S. P.; RULE, D. W.; WILlSE, A. R.; CLARK, T. L.; STORER, N. P.; FLANNAGAN, R. D.; SAMUEL, L. W.; MEINKE, L. J. Evaluation of SmartStax and SmartStax PRO maize against western corn rootworm and northern corn rootworm: efficacy and resistance management. Pest Management Science, v. 73, n. 9, p. 18831899, 2017. DOI: 10.1002/ps.4554.

HILKER, M.; MEINERS, T. Early herbivore alert: insect eggs induce plant defense. Journal of Chemical Ecology, v. 26, p. 1379-1397, 2006. DOI: 10.1007/s10886-006-9057-4.

ISAAA. International Service for teh Acquisition of Agri-Biotech Applictions. Global status of commercialized biotech/GM crops: 2016 . Ithaca, 2018. (ISAAA. Brief n. 52).

KJAER, C.; DAMGAARD, C.; LAURITZEN, A. Assessment of effect of Bt-oilseed rape on large white butterfly (Pieris brassicae) in natural habitats. Entomologia Experimentalis et Applicata, v. 134, n. 3, p. 304-311, 2010. DOI: 10.1111/j.1570-7458.2009.00958.x.

LEI, Z.; LIU, T.; GREENBERG, S. Feeding, oviposition and survival of Liriomyza trifolii (Diptera: Agromyzidae) on $\mathrm{Bt}$ and non- $\mathrm{Bt}$ cottons. Bulletin of Entomological Research, v. 99 , n. 3, p. 253-261, 2009. DOI: 10.1017/ S0007485308006317.

LEUCK, D. B.; PERKINS, W. D. A method of estimating fall armyworm progeny reduction when evaluating control achived host-plant resistance. Journal of Economic Entomology, v. 65 , n. 2, p. 482-483, 1972. DOI: 10.1093/ jee/65.2.482.

MONTEZANO, D. G.; SPECHT, A.; SOSAGÓMEZ, D. R.; ROQUE-SPECHT, V. F.; SOUSA-SILVA, J. C.; PAULA-MORAES, S. V.; PETERSON, J. A.; HUNT, T. E. Host plants of Spodoptera frugiperda (Lepidoptera: Noctuidae) in the Americas. African Entomology, v. 26, n. 2, p. 286-300, 2018. DOI: $10.4001 / 003.026 .0286$

MUSSER, R. A.; HUM-MUSSER, S.; EICHENSEER, H.; PEIFFER, M.; ERVIN, G.; MURPHY, B.; FELTON, G. W. Caterpillar saliva beats plant defences: a new weapon emerges in 
the evolutionary arms race between plants and herbivores. Nature, v. 416, n. 6881, p. 599-600, 2002. DOI: $10.1038 / 416599 a$

PEÑAFLOR, M. F.; ERB, M.; ROBERT, C. A.; MIRANDA, L. A.; WERNEBURG, A. G.; DOSSI, F. C. A.; TURLINGS, T. C. J.; BENTO, J. M. Oviposition by a moth suppresses constitutive and herbivore-induced plant volatiles in maize. Planta, v. 234, p. 207-215, 2011. DOI: 10.1007/ s00425-011-1409-9.

PITRE, H. N.; MULROONEY, J. E.; HOGG, D. B. Fall armyworm (Lepidoptera: Noctuidae) oviposition: crop preferences and egg distribution on plants. Journal of Economic Entomology, v. 76, n. 3, p. 463-466, 1983. DOI: 10.1093/ jee/76.3.463.

R DEVELOPMENT CORE TEAM. R: a language and environment for statistical computing. Vienna: R Foundation for Statistical Computing, 2014. 977 p.

REFSNIDER, J. M.; JANZEN, F. J. Putting eggs in one basket: ecological and evolutionary hypotheses for variation in oviposition-site choice. Annual Review of Ecology, Evolution, and Systematics, v. 41, p. 39-57, 2010. DOI: 10.1146/annurev-ecolsys-102209-144712.

ROJAS, J. C.; KOLOMIETS, M. V.; BERNAL, J. S. Nonsensical choices? Fall armyworm moths choose seemingly best or worst hosts for their larvae, but neonate larvae make their own choices. PLoS ONE, v. 13, n. 5, e0197628, 2018. DOI: 10.1371/journal.pone.0197628.

SCHULER, T. H.; POTTING, R. P.; DENHOLM, I.; POPPY, G. M. Parasitoid behaviour and Bt plants. Nature, v. 400, p. 825-829, 1999. DOI: $10.1038 / 23605$.
SPARKS, A. N. A review of the biology of the fall armyworm. Florida Entomologist, v. 62, n. 2, p. 82-87, 1979.

STORER, N. P.; THOMPSON, G. D.; HEAD, G. P. Application of pyramided traits against Lepidoptera in insect resistance management for Bt crops. GM Croops \& Food, v. 3, n. 3, p. 154162, 2012. DOI: 10.4161/gmcr.20945.

TÉLLEZ-RODRÍGUEZ, P.; RAYMOND, B.; MORÁN-BERTOT, I.; RODRÍGUEZCABRERA, L.; WRIGHT, D. J.; BORROTO, C. G.; AYRA-PARDO, C. Strong oviposition preference for $\mathrm{Bt}$ over non-Bt maize in Spodoptera frugiperda and its implications for the evolution of resistance. BMC Biology, v. 12, article 48, 2014. DOI: 10.1186/1741-7007-12-48.

THOMPSON, J. N. Evolutionary ecology of the relationship between oviposition preference and performance of offspring in phytophagous insects. Entomologia Experimentalis ett Applicata, v. 47, n. 1, p. 3-14, 1988. DOI: 10.1111/j.1570-7458.1988.tb02275.x.

VALICENTE, F. H.; BARRETO, M. R. Bacillus thuringiensis survey in Brazil: geographical distribution and insecticidal activity against Spodoptera frugiperda (J.E. Smith) (Lepidoptera: Noctuidae). Neotropical Entomology, v. 32, n. 4, p. 639-644, 2003. DOI: 10.1590/S1519$566 \times 2003000400014$. 